\title{
Study on the Complex Formation and the Ion-Association of Anionic Chelate of Molybdenum(VI) with Bidentate Ligand and the Cation of 2,3,5-Triphenyl-2H-tetrazolium Chloride
}

\author{
Kirila Stojnova, ${ }^{1}$ Petya Racheva, ${ }^{2}$ Vidka Divarova, ${ }^{2}$ Pavel Yanev ${ }^{1}$ \\ and Vanya Lekova ${ }^{1, *}$ \\ ${ }^{1}$ Department of General and Inorganic Chemistry with Methodology of Chemistry Education, Faculty of Chemistry, \\ Plovdiv University "Paisii Hilendarski", 24 Tsar Assen Street, Plovdiv 4000, Bulgaria \\ ${ }^{2}$ Department of Chemical Sciences, Faculty of Pharmacy, Medical University-Plovdiv, 15A Vasil Aprilov Boulevard, \\ Plovdiv 4002, Bulgaria \\ *Corresponding author: E-mail: vanlek@uni-plovdiv.bg \\ tel.: +35932261420
}

Received: 10-01-2019

\begin{abstract}
The complex formation between the anionic chelate of molybdenum(VI) with the bidentate ligand of 3,5-dinitrocatechol (3,5-DNC) and its ion-association with the cation of 2,3,5-triphenyl-2H-tetrazolium chloride (TTC) in the liquid-liquid extraction system $\mathrm{Mo}(\mathrm{VI})-3,5-\mathrm{DNC}-\mathrm{TTC}-\mathrm{H}_{2} \mathrm{O}-\mathrm{CHCl}_{3}$ were studied by spectrophotometry. The validity of Beer's law was checked and some analytical characteristics of the system were calculated under the optimum conditions for the chelate formation and extraction. The effect of various co-existing ions and reagents on the process of chelate formation and ion-association was investigated. The molar ratio of the components in the ion-associated complex Mo(VI)-3,5DNC-TTC was determined by independent methods. The association process in aqueous phase and the extraction equilibria were investigated and quantitatively characterized by the following equilibrium constants: association constant, distribution constant, extraction constant and recovery factor. Based on this, a reaction scheme, a general formula and a structural formula of the complex were suggested.
\end{abstract}

Keywords: Molybdenum(VI); bidentate ligand; chelate formation; extraction equilibriums

\section{Introduction}

The molybdenum is a transition metal with rich coordination chemistry, it occurs in various oxidation states, coordination numbers and geometries. ${ }^{1-3}$ Molybdenum(VI) forms complexes with various organic ligands, such as polyphenols and their functional derivatives, polyhydroxycarboxylic acids, aminopolycarboxylic acids, hydroxamic acids, amines (primary, secondary and ternary), 8-hydroxyquinoline and its derivatives, aldehyde hydrazones, oximes, $\beta$-diketones, fluorones, hydroxyazodyes, biomolecules (chitosan, chitin, D-glucosamine, L-alanine, L-phenylalanine). ${ }^{4-17}$ Molybdenum(VI) complexes with bidentate ligands, containing $[\mathrm{S}, \mathrm{S}],[\mathrm{S}, \mathrm{O}],[\mathrm{S}, \mathrm{N}]$ donor atoms, like toluene-3,4-dithiol, 2-mercaptophenol, 2-amino- thiophenol, ethane-1,2-dithiol, dithiooxamide, 2-thiopheno-carboxamide, were obtained and structurally characterized. ${ }^{18}$ Molybdenum(VI) gives colored anionic chelates with bidentate ligands of aromatic compounds, containing two or more hydroxyl groups in $o$-position relative to each other. 1,2-Dihydroxybenzene, 1,2,3,-trihydroxybenzene and 3,4,5-trihydroxybenzoic acid form colored bidentate chelates, while phenol, 1,3-dihydroxybenzene and 1,4-dihydroxybenzene do not form colored chelates in the $\mathrm{pH}$ range 1.1-10.9. ${ }^{4}$ The colored anionic chelates of molybdenum(VI) form ion-associated complexes with bulky organic cations, like methyltrioctylammonium, cetylpyridinium, cetyltrimethylammonium, tetraphenylphosphonium., ${ }^{4,19-21}$

The ion-associated complexes of anionic chelates of metals with various natural organic and inorganic ligands 
with $\mathrm{N}$-, S- and O-containing donor atoms and with the participation of mono- and ditetrazolium cations are a special scientific research field of the chemistry of the coordination compounds. It is up-to-date topic, not only as a theoretical background for the preparation of novel ion-associated complexes, but mainly due to the possibility for their application in the Analytical Chemistry for determination of various metals in natural, industrial, pharmaceutical and biological samples, addressing in such a way a number of ecological issues. Tetrazolium salts are used as reagents for the preparation of various ion-associated complexes of metals, e.g. W(VI), Ge(IV), Tl(III), $\mathrm{Nb}(\mathrm{V})$, $\mathrm{V}(\mathrm{V}), \mathrm{Ga}(\mathrm{III}), \mathrm{Co}(\mathrm{II}), \mathrm{Ge}(\mathrm{IV}) .{ }^{22-31}$ The structure and properties of mono- and ditetrazolium salts, the bulky hydrophobic organic substituents in their molecules, determine their ability to form ion-associated complexes, increasing the extractability in non-polar solvents. The presence of a quaternary nitrogen atom in the molecules of the tetrazolium salts determines the ability to form ionic associates in the aqueous phase without protonation, as opposed to the amines. $22,32,33$

The liquid-liquid extraction is a part of the chemistry of the solutions and the coordination compounds. It is applied to study the processes of complex formation and the extraction equilibria. The extraction spectrophotometry is a relatively simple, convenient, rapid to perform and inexpensive method for preparation and characterization of new complex compounds as well as for their application in the chemical analysis. ${ }^{34-40}$

The aim of our current investigation was to synthesize molybdenum(VI) ion-associated complex in liquid-liquid extraction system and estimate its feasibility in analytical chemistry of $\mathrm{Mo}(\mathrm{VI})$, in order to evaluate the possible applications of the system for determination of traces of molybdenum(VI) in alloys, biological, medical and pharmaceutical samples. The extraction equilibria of the chelate formation between molybdenum(VI) with the bidentate ligand of 3,5-dinitrocatechol (3,5-DNC) and the cation of 2,3,5-triphenyl-2H-tetrazolium chloride (TTC) in the liquid-liquid system $\mathrm{Mo}(\mathrm{VI})-3,5-\mathrm{DNC}-\mathrm{TTC}-$ $\mathrm{H}_{2} \mathrm{O}-\mathrm{CHCl}_{3}$ was study spectrophotometrically.

\section{Experimental}

\section{1. Reagents and Apparatus}

$\mathrm{Na}_{2} \mathrm{MoO}_{4} \cdot 2 \mathrm{H}_{2} \mathrm{O}$ (Fluka AG, p.a.): an aqueous $1.6 \times$ $10^{-2} \mathrm{~mol} \mathrm{~L}^{-1}$ solution was prepared.

3,5-Dinitrocatechol (3,5-DNC) (Sigma-Aldrich, p.a.): 3,5-DNC was dissolved in $\mathrm{CHCl}_{3}$ to give a $1.0 \times 10^{-2} \mathrm{~mol} \mathrm{~L}^{-1}$ solution. 2,3,5-triphenyl-2H-tetrazolium chloride (TTC) (Loba Feinchemie, p.a.): an aqueous $3.0 \times 10^{-3} \mathrm{~mol} \mathrm{~L}^{-1}$ solution was prepared. $\mathrm{H}_{2} \mathrm{SO}_{4}$ (95-97\% for analysis, Merck): 9 mol L-1 solution was prepared. The concentration of $\mathrm{H}_{2} \mathrm{SO}_{4}$ was determined titrimetrically. A Camspec M508 spectrophotometer (UK), equipped with $10 \mathrm{~mm}$ path length cells, was employed for measurement of the absorbance. The organic solvent $\mathrm{CHCl}_{3}$ was additionally distilled.

\section{2. Procedure for Establishment of the Optimum Conditions for Chelate Formation and Ion-Association}

The required aliquots of the solutions of $\mathrm{Mo}(\mathrm{VI})$, TTC and $\mathrm{H}_{2} \mathrm{SO}_{4}$ were introduced into $250 \mathrm{~mL}$ separatory funnels. The resulting solutions were diluted with distilled water to a total volume of $10 \mathrm{~mL}$. A required aliquot of a chloroform solution of 3,5-DNC was added and then the organic phase was adjusted to a volume of $10 \mathrm{~mL}$ with chloroform. The funnels were shaken for a fixed time (up to 300 s). A portion of the organic extract was filtered through a filter paper into a $1 \mathrm{~cm}$ cell and the absorbance was measured against a blank. The blank extraction was performed in the same manner in the absence of molybdenum. ${ }^{29}$

\section{3. Procedure for Determination of the Distribution Constant}

The distribution constant $\left(K_{D}\right)$ can be calculated according to the ratio $K_{D}=A_{1} /\left(A_{3}-A_{1}\right)$, where $A_{1}$ and $A_{3}$ are respectively the light absorbance after a single extraction in chloroform under optimum operating conditions and after a triple extraction performed under the same conditions. Single extraction: the single extraction was performed under the optimum conditions for chelate formation (Table 1, column 1). The organic layer was transferred into $25 \mathrm{~mL}$ calibrated flask and the flask was brought to volume with chloroform. The measurement of the light absorbance $A_{1}$ is done against a blank sample, prepared under the same conditions. Triple extraction: the first stage of the triple extraction is performed with $10 \mathrm{~mL}$ of chloroform and the extract is transferred into a $25 \mathrm{~mL}$ calibrated flask. During the second stage of the extraction, $8 \mathrm{~mL}$ of chloroform are added to the aqueous phase remaining after the first stage. The organic layer is added to that from the first stage. For the third stage of extraction, $7 \mathrm{~mL}$ of chloroform are added to the aqueous phase remaining after the second stage and for the third time an extraction is performed. The organic layer is transferred to the previous two. The calibrated flask is brought to volume with chloroform. The measurement of $A_{3}$ is performed against a blank sample prepared in the same way. ${ }^{41}$

\section{Results and Discussion}

\section{1. Optimum Extraction- Spectrophotometric Conditions for Chelate Formation and Ion-Association}

The colored anionic chelate of molybdenum(VI) with the bidentate ligand of 3,5-dinitrocatrchol (3,5- 
DNC) was extracted in chloroform in the presence of the bulky hydrophobic monotetrazolium cation of 2,3,5-triphenyl-2H-tetrazolium chloride (TTC). The absorption spectrum of the extract of the studied ion-associated complex $\mathrm{Mo}(\mathrm{VI})-3,5-\mathrm{DNC}-\mathrm{TTC}$ in $\mathrm{CHCl}_{3}$ was characterized by an absorption maximum in the visible range $\left(\lambda_{\max }=410 \mathrm{~nm}\right)$ (Figure 1$)$. The acidity of the aqueous phase influences the extraction of the anionic chelate $\mathrm{Mo}(\mathrm{VI})-3,5-\mathrm{DNC}$ into the organic phase in the form of ion-associate with the tetrazolium cation of TTC. The maximum and constant extraction of the ion-associated complex is achieved in strongly acidic solution of $\mathrm{H}_{2} \mathrm{SO}_{4}$ $\left((0.9-7.2) \times 10^{-1} \mathrm{~mol} \mathrm{~L}^{-1}\right)$ (Figure 2). The results from the experiments showed that the extraction equilibrium cannot be achieved within less than $120 \mathrm{~s}$. The prolonged shaking does not have an impact on the absorbance. The next experiments were performed for $3 \mathrm{~min}$. The concentrations of the reagents are the most important factor, influencing the extraction equilibrium. The chelate formation of $\mathrm{Mo}(\mathrm{VI})-3,5-\mathrm{DNC}$ requires 6.25 -fold excess of 3,5-DNC $\left(\geq 1.0 \times 10^{-3} \mathrm{~mol} \mathrm{~L}^{-1}\right)$ and 1.13-fold excess of TTC $\left(\geq 1.8 \times 10^{-4} \mathrm{~mol} \mathrm{~L}^{-1}\right)$ for maximum association and extraction.

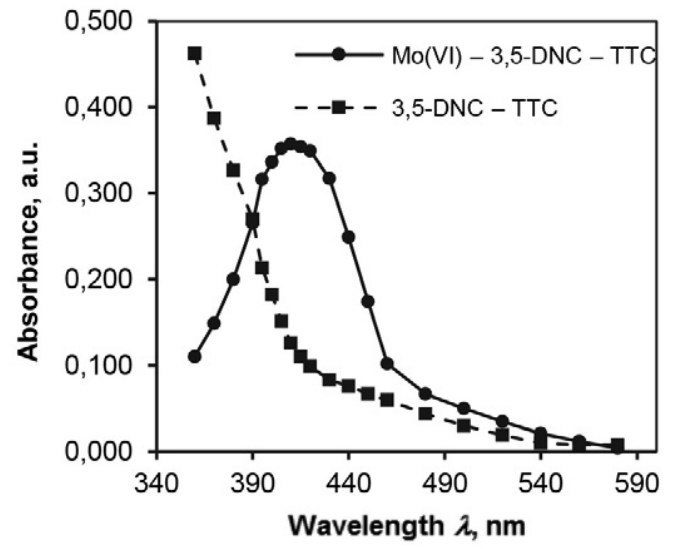

Figure 1. Absorption spectra of the complex $\mathrm{Mo}(\mathrm{VI})-3,5-\mathrm{DNC}-$ TTC and of the blank sample 3,5-DNC-TTC in $\mathrm{CHCl}_{3} \mathrm{C}_{\mathrm{Mo}(\mathrm{VI})}=1.6$ $\times 10^{-5} \mathrm{~mol} \mathrm{~L}^{-1} ; C_{3,5-\mathrm{DNC}}=1.2 \times 10^{-3} \mathrm{~mol} \mathrm{~L}^{-1}, C_{\mathrm{TTC}}=2.4 \times 10^{-4} \mathrm{~mol}$ $\mathrm{L}^{-1} ; C_{\mathrm{H} 2 \mathrm{SO} 4}=4.5 \times 10^{-1} \mathrm{~mol} \mathrm{~L}^{-1} ; \lambda=410 \mathrm{~nm} ; \tau=3 \mathrm{~min}$

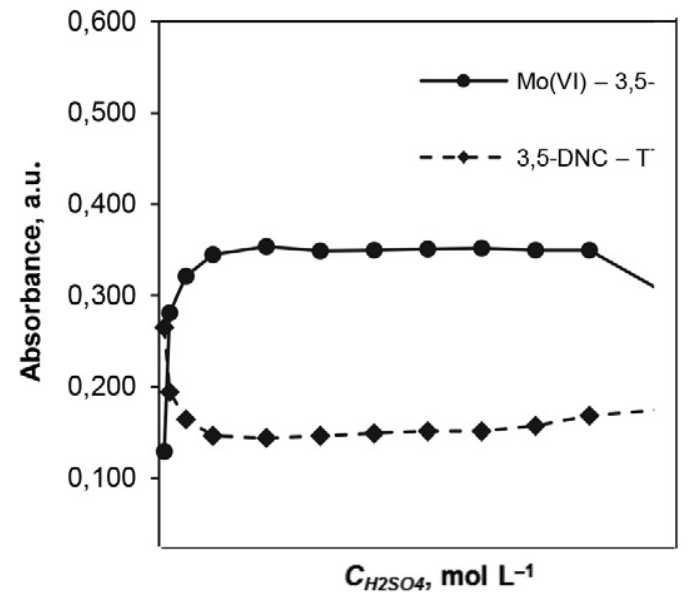

Figure 2. Absorption spectra of the complex $\mathrm{Mo}(\mathrm{VI})-3,5-\mathrm{DNC}-$ TTC in $\mathrm{CHCl}_{3}$ against 3,5-DNC-TTC extract vs. acidity of the aqueous phase: $C_{\mathrm{Mo}(\mathrm{VI})}=1.6 \times 10^{-5} \mathrm{~mol} \mathrm{~L}^{-1} ; C_{3,5-\mathrm{DNC}}=1.2 \times 10^{-3}$ $\mathrm{mol} \mathrm{L}-1, C_{\mathrm{TTC}}=2.4 \times 10^{-4} \mathrm{~mol} \mathrm{~L}^{-1} ; \lambda=410 \mathrm{~nm} ; \tau=3 \mathrm{~min}$

The optimum experimental conditions for the extraction of the ion-associated complex Mo(VI)-3,5-DNCTTC are summarized in Table 1, column 1.

\section{2. Beer's Law, Apparent Molar Absorptivity and other Analytical Characteristics}

The range of agreement with Beer's law, i.e. the linear relationship between the molybdenum concentration in the aqueous phase $\left(C_{\mathrm{Mo}(\mathrm{VI})}, \mu \mathrm{g} \mathrm{mL} \mathrm{m}^{-1}\right)$ and the absorbance of the ion-association complex in the organic phase after extraction regression analysis under the optimum conditions for complex formation was used. The equation of a straight line was found to be $\mathrm{Y}=0.1806 \mathrm{X}+0.0022$ with a correlation coefficient squared 0.9994 . Under the optimum conditions for complex formation, the linearity is observed for concentrations up to $6.72 \mu \mathrm{g} \mathrm{mL} \mathrm{L}^{-1} \mathrm{Mo}(\mathrm{VI})$. Further analytical characteristics, e.g. apparent molar absorptivity $\varepsilon^{\prime}$, Sandell's sensitivity, limit of detection and limit of quantification, are shown in Table 1, column 2.

From the analytical characteristics of the extraction system $\mathrm{Mo}(\mathrm{VI})-3,5-\mathrm{DNC}-\mathrm{TTC}-\mathrm{H}_{2} \mathrm{O}-\mathrm{CHCl}_{3}$, it can be

Table 1. Optimum extraction-spectrophotometric conditions and analytical characteristics of the system $\mathrm{Mo}(\mathrm{VI})-3,5-\mathrm{DNC}-\mathrm{TTC}-\mathrm{H}_{2} \mathrm{O}-\mathrm{CHCl}_{3}$

\begin{tabular}{ll}
\hline Optimum conditions & Analytical characteristic \\
\hline Absorption maximum $\left(\lambda_{\max }\right) 410 \mathrm{~nm}$ & $\begin{array}{l}\text { Apparent molar absorptivity }\left(\varepsilon^{\prime}\right) \\
(2.16 \pm 0.03) \times 10^{4} \mathrm{~L} \mathrm{~mol}^{-1} \mathrm{~cm}^{-1}\end{array}$ \\
& True molar absorptivity $(\varepsilon)$ \\
Volume of the aqueous phase $10 \mathrm{~mL}$ & $(2.01 \pm 0.04) \times 10^{4} \mathrm{~L} \mathrm{~mol}^{-1} \mathrm{~cm}^{-1}$ \\
Volume of the organic phase $10 \mathrm{~mL}$ & Sandell's sensitivity (SS) $4.45 \mathrm{ng} \mathrm{cm}^{-2}$ \\
Concentration of $\mathrm{H}_{2} \mathrm{SO}_{4}$ in the aqueous phase & Adherence to Beer's law \\
$(0.9 \div 7.2) \times 10^{-1} \mathrm{~mol} \mathrm{~L}^{-1}$ & up to $6.72 \mu \mathrm{cm}^{-3}$ \\
Shaking time $(\tau) 3 \mathrm{~min}$ & Relative standard deviation $(\mathrm{RSD}) 1.17 \%$ \\
Concentration of $3,5-\mathrm{DNC} \geq 1.0 \times 10^{-3} \mathrm{~mol} \mathrm{~L}^{-1}$ & Limit of detection (LOD) $0.19 \mu \mathrm{g} \mathrm{mL}$ \\
Concentration of TTC $\geq 1.8 \times 10^{-4} \mathrm{~mol} \mathrm{~L}^{-1}$ & Limit of quantification (LOQ) $0.62 \mu \mathrm{g} \mathrm{mL} \mathrm{mL}^{-1}$ \\
\hline
\end{tabular}


concluded that the ion-associate formed between the anionic chelate of $\mathrm{Mo}(\mathrm{VI})$ with the bidentate ligand of 3,5DNC and the monotetrazolium cation allows determination of $\mathrm{Mo}(\mathrm{VI})$ with a high sensitivity.

\section{3. Effect of Co-Existing Ions and Reagents on the Complex Formation}

The effect of various co-existing ions and reagents on the process of the association in aqueous phase and the extraction equilibria was studied under optimum extraction conditions (Table 1, column 1). The concentration of $\mathrm{Mo}(\mathrm{VI})$ in the presence of the co-existing ions and reagents was determined from the sequence of Beer's law. A deviation of $\pm 3 \%$ from the absorbance of the complex in the absence of co-existing ions was accepted as an interfering effect. The results are presented in Table 2. From them, it can be concluded that most of the ions studied do not interfere, but some of them, like $\mathrm{Al}(\mathrm{III}), \mathrm{Fe}(\mathrm{II})$ and $\mathrm{Cr}(\mathrm{VI})$ in concentrations higher than the indicated ones, hinder

Table 2. Effect of co-existing ions and reagents on the complex formation of the ion-associate $\mathrm{Mo}(\mathrm{VI})-3,5-\mathrm{DNC}-\mathrm{TTC}$ for extraction in the presence of $20 \mu \mathrm{g} \mathrm{Mo}(\mathrm{VI})$

\begin{tabular}{|c|c|c|c|}
\hline $\begin{array}{l}\text { Co-existing ion } \\
\text { and reagent }\end{array}$ & $\begin{array}{c}\text { Co-existing } \\
\text { ion and reagent, } \\
\mu \mathrm{g} / 10 \mathrm{~cm}^{3} \\
\text { aqueous phase }\end{array}$ & $\begin{array}{l}\text { Mo(VI) } \\
\text { found, } \mu \mathrm{g}\end{array}$ & $\mathrm{R}, \%$ \\
\hline $\mathrm{Na}^{+}$ & 10000 & 20.19 & 100.95 \\
\hline $\mathrm{K}^{+}$ & 10000 & 20.24 & 101.20 \\
\hline $\mathrm{Mg}^{2+}$ & 10000 & 19.87 & 99.35 \\
\hline $\mathrm{Ca}^{2+}$ & 10000 & 19.77 & 98.85 \\
\hline $\mathrm{Cu}^{2+}$ & 10000 & 19.95 & 99.75 \\
\hline $\mathrm{Zn}^{2+}$ & 10000 & 19.63 & 98.15 \\
\hline $\mathrm{Cd}^{2+}$ & 10000 & 20.46 & 102.30 \\
\hline $\mathrm{Ni}^{2+}$ & 10000 & 20.29 & 101.45 \\
\hline $\mathrm{Mn}^{2+}$ & 10000 & 20.01 & 100.05 \\
\hline $\mathrm{Co}^{2+}$ & 10000 & 19.92 & 99.60 \\
\hline $\mathrm{Al}^{3+}$ & 4000 & 20.32 & 101.61 \\
\hline $\mathrm{Cr}^{3+}$ & 10000 & 19.97 & 99.83 \\
\hline $\mathrm{Fe}^{2+}$ & 750 & 20.20 & 101.02 \\
\hline $\mathrm{Fe}^{3+}$ & 100 & 17.59 & 87.95 \\
\hline $\mathrm{V}(\mathrm{V})$ & 100 & 21.17 & 105.87 \\
\hline $\mathrm{Nb}(\mathrm{V})$ & 50 & 15.94 & 79.68 \\
\hline $\mathrm{Cr}(\mathrm{VI})$ & 100 & 19.91 & 99.56 \\
\hline $\mathrm{W}(\mathrm{VI})$ & 50 & 25.06 & 125.32 \\
\hline $\mathrm{F}^{-}$ & 10000 & 19.96 & 99.79 \\
\hline $\mathrm{Br}^{-}$ & 10000 & 20.22 & 101.08 \\
\hline $\mathrm{NO}_{3}^{-}$ & 2500 & 20.82 & 104.09 \\
\hline $\mathrm{PO}_{4}{ }^{3^{-}}$ & 10000 & 20.42 & 102.10 \\
\hline $\mathrm{P}_{2} \mathrm{O}_{7}^{4-}$ & 10000 & 20.37 & 101.83 \\
\hline $\mathrm{CH}_{3} \mathrm{COO}^{-}$ & 10000 & 20.43 & 102.16 \\
\hline $\mathrm{C}_{4} \mathrm{H}_{4} \mathrm{O}_{6}{ }^{2^{-}}$ & 10000 & 19.94 & 99.69 \\
\hline $\mathrm{C}_{6} \mathrm{H}_{5} \mathrm{O}_{7}^{3^{-}}$ & 10000 & 20.20 & 101.02 \\
\hline Complexone III & 10000 & 20.03 & 100.15 \\
\hline Complexone IV & 10000 & 20.10 & 100.52 \\
\hline L-Ascorbic acid & 1000 & 20.21 & 101.05 \\
\hline
\end{tabular}

the extraction of $\mathrm{Mo}(\mathrm{VI})$ as an associated complex with 3,5-DNC and TTC. The extraction equilibrium is severely interfered by $\mathrm{Fe}(\mathrm{III}), \mathrm{V}(\mathrm{V})$ and $\mathrm{W}(\mathrm{VI})$ ions at very low concentrations. The interfering ions can be masked or removed from the extraction system to avoid this. Our investigations as well as the studies published in the literature show that same of the co-existing ions, like $\mathrm{Al}(\mathrm{III})$, $\mathrm{Fe}(\mathrm{II})$ and $\mathrm{Fe}(\mathrm{III})$ can be removed by their pre-precipitation with $\mathrm{OH}^{-}$at $\mathrm{pH}=11 .{ }^{42}$ Vanadium(V) can be co-precipitated with $\mathrm{Fe}(\mathrm{III})$ in alkali medium. ${ }^{43}$ The co-existing ions, like $\mathrm{Fe}(\mathrm{II}), \mathrm{Fe}(\mathrm{III})$ and $\mathrm{Al}(\mathrm{III})$ can be masked with added Complexone III, Complexone IV or L-ascorbic acid in concentrations lower than the indicated.

\section{4. Molar Ratios of the Ion-Associated Complex}

The molar ratios of the ion-associated complex were determined by three independent methods: the mobile equilibrium method, the straight-line method of Asmus and the method of continuous variations. ${ }^{44}$

The mobile equilibrium method and the straightline method of Asmus were applied to prove the molar ratios Mo(VI):3,5-DNC and Mo(VI):TTC. The results from the application of these methods are shown in Figures 3-5, respectively.

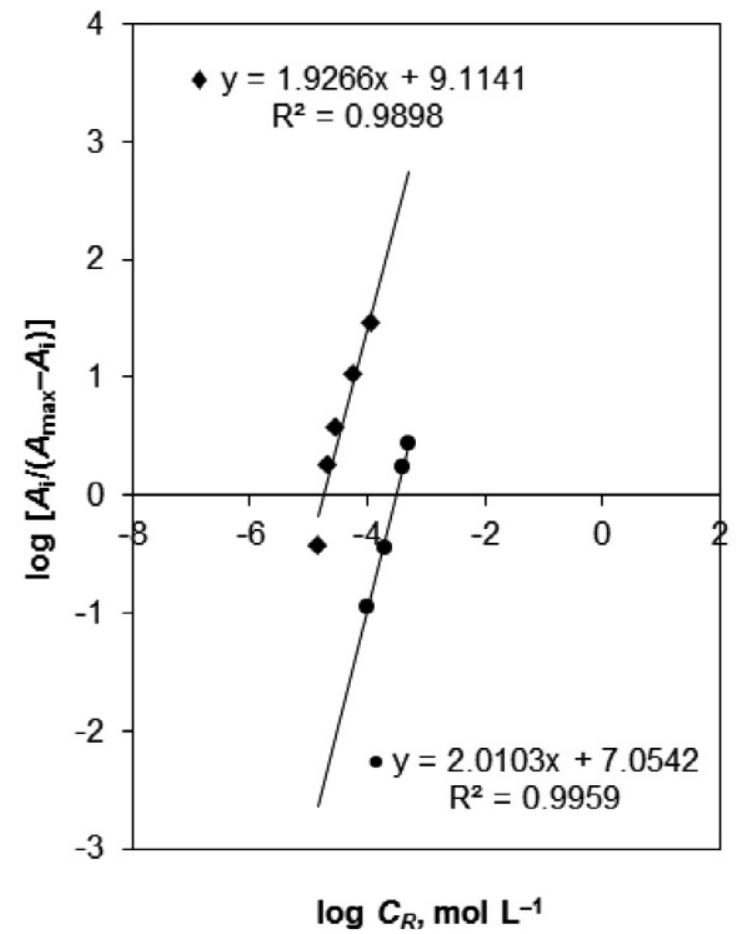

Figure 3. Straight lines by the mobile equilibrium method for determination of the molar ratios $\mathrm{Mo}(\mathrm{VI}): 3,5-\mathrm{DTC}$ and $\mathrm{Mo}(\mathrm{VI})$ :TTC $C_{\mathrm{Mo}(\mathrm{VI})}=1.6 \times 10^{-5} \mathrm{~mol} \mathrm{~L}^{-1} ; C_{\mathrm{H} 2 \mathrm{SO} 4}=4.5 \times 10^{-1} \mathrm{~mol} \mathrm{~L}^{-1} ; \lambda=410 \mathrm{~nm}$; $\tau=3 \mathrm{~min}$

- $\mathrm{Mo}(\mathrm{VI}): 3,5-\mathrm{DNC}, C_{\mathrm{TTC}}=2.4 \times 10^{-4} \mathrm{~mol} \mathrm{~L}^{-1}$;

- Mo(VI) : TTC, $C_{3,5-\mathrm{DNC}}=1.2 \times 10^{-3} \mathrm{~mol} \mathrm{~L}^{-1}$ 


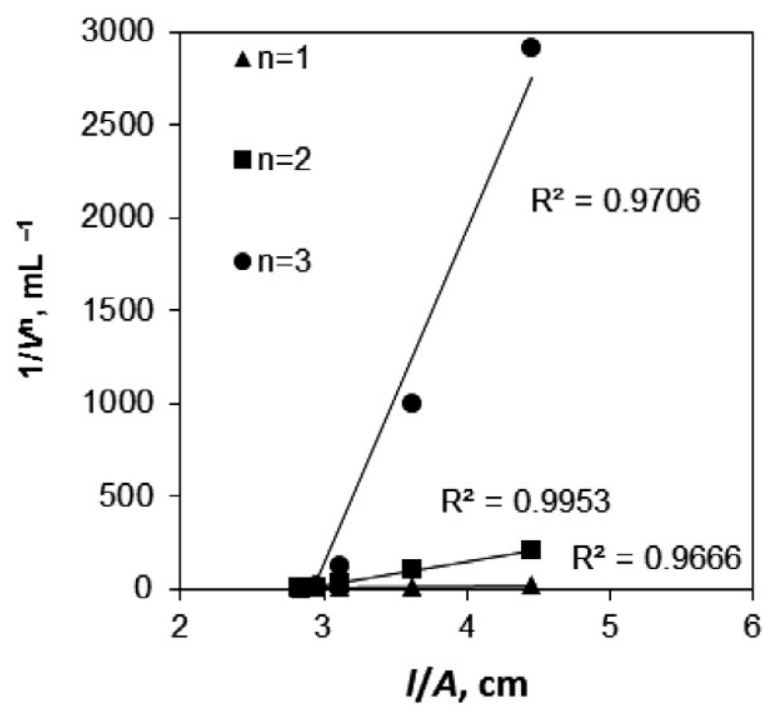

Figure 4. Determination of the molar ratio (n) Mo(VI):TTC by the method of Asmus $C_{\mathrm{Mo}(\mathrm{VI})}=1.6 \times 10^{-5} \mathrm{~mol} \mathrm{~L}^{-1} ; C_{3,5-\mathrm{DNC}}=1.2 \times 10^{-3}$ $\mathrm{mol} \mathrm{L}-1 C_{\mathrm{H} 2 \mathrm{SO} 4}=4.5 \times 10^{-1} \mathrm{~mol} \mathrm{~L}^{-1} ; \lambda=410 \mathrm{~nm} ; \tau=3 \mathrm{~min}$

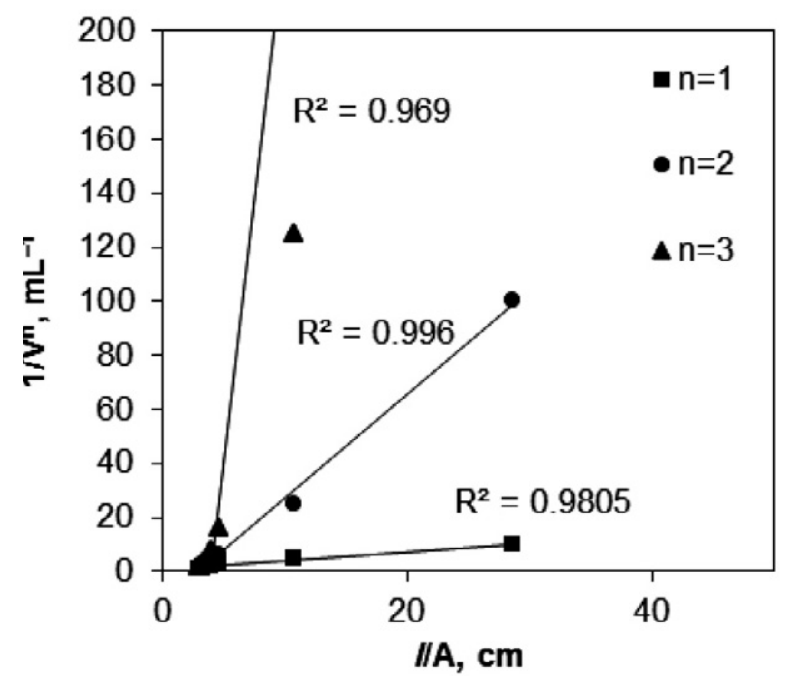

Figure 5. Determination of the molar ratio (n) Mo(VI):3,5-DNC by the method of Asmus $C_{\mathrm{Mo}(\mathrm{VI})}=1.6 \times 10^{-5} \mathrm{~mol} \mathrm{~L}^{-1} ; C_{\mathrm{TTC}}=2.4 \times 10^{-4}$ $\mathrm{mol} \mathrm{L}{ }^{-1} ; C_{\mathrm{H} 2 \mathrm{SO} 4}=4,5 \times 10^{-1} \mathrm{~mol} \mathrm{~L}^{-1} ; \lambda=410 \mathrm{~nm} ; \tau=3 \mathrm{~min}$

On the basis of the results it can be concluded that $\mathrm{Mo}(\mathrm{VI}), 3,5-\mathrm{DNC}$ and TTC interact in molar ratio 1:2:2. The application of the method of continuous variations confirmed the molar ratio $\mathrm{Mo}(\mathrm{VI}): \mathrm{TTC}=1: 2$ (Figure 6).

\section{5. Reaction Scheme and Suggested General Formula}

The carried out experiments showed that the chelate formation and the extraction of the ion-associated complex occurred in strongly acidic solution. Under these conditions, the chelate formation between molybdenum(VI) and the bidentate ligand 3,5-dinitrocatechol (3,5-DNC) is given by the equation (1):

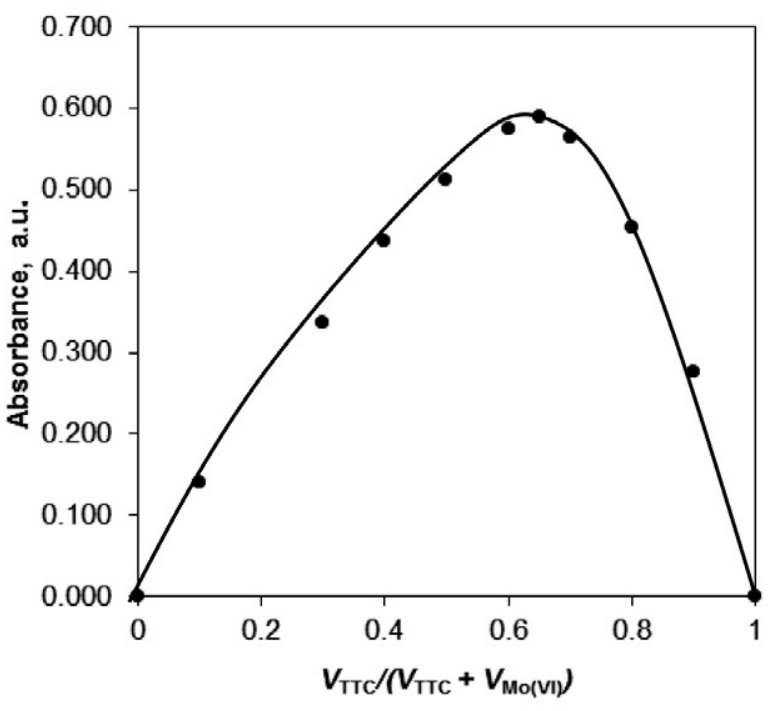

Figure 6. Determination of the molar ratio (n) Mo(VI):TTC by the method of continuous variations $C_{\mathrm{Mo}(\mathrm{VI})}+C_{\mathrm{TTC}}=8.0 \times 10^{-5} \mathrm{~mol}$ $\mathrm{L}^{-1} ; C_{3,5-\mathrm{DNC}}=1.2 \times 10^{-3} \mathrm{~mol} \mathrm{~L}^{-1} ; C_{\mathrm{H} 2 \mathrm{SO} 4}=4.5 \times 10^{-1} \mathrm{~mol} \mathrm{~L}^{-1} ; \lambda=$ $410 \mathrm{~nm} ; \tau=3 \mathrm{~min}$

$$
\begin{aligned}
& \mathrm{MoO}_{4}{ }^{2-}+2(\mathrm{HO})_{2} \mathrm{C}_{6} \mathrm{H}_{2}\left(\mathrm{NO}_{2}\right)_{2} \rightleftharpoons \\
& \left\{\mathrm{MoO}_{2}\left[\mathrm{O}_{2} \mathrm{C}_{6} \mathrm{H}_{2}\left(\mathrm{NO}_{2}\right)_{2}\right]_{2}\right\}^{2-}+2 \mathrm{H}_{2} \mathrm{O}
\end{aligned}
$$

Having in mind the reaction of chelate formation of $\mathrm{Mo}(\mathrm{VI})-3,5-\mathrm{DNC}$ and the molar ratio indicated above, it can be suggested that the formation of the ion-associate in the aqueous phase, its distribution between the aqueous and the organic phases and its extraction in chloroform can be given by the following equations (2-4).

$$
\begin{aligned}
& 2(\mathrm{TTC})^{+}{ }_{\text {(aq) }}+\left\{\mathrm{MoO}_{2}\left[\mathrm{O}_{2} \mathrm{C}_{6} \mathrm{H}_{2}\left(\mathrm{NO}_{2}\right)_{2}\right]_{2}\right\}^{2-}{ }_{(\mathrm{aq})} \\
& (\mathrm{TTC})_{2}\left\{\mathrm{MoO}_{2}\left[\mathrm{O}_{2} \mathrm{C}_{6} \mathrm{H}_{2}\left(\mathrm{NO}_{2}\right)_{2}\right]_{2}\right\}_{(\mathrm{aq})} \\
& (\mathrm{TTC})_{2}\left\{\mathrm{MoO}_{2}\left[\mathrm{O}_{2} \mathrm{C}_{6} \mathrm{H}_{2}\left(\mathrm{NO}_{2}\right)_{2}\right]_{2}\right\}_{(\mathrm{aq})} \rightleftharpoons \\
& (\mathrm{TTC})_{2}\left\{\mathrm{MoO}_{2}\left[\mathrm{O}_{2} \mathrm{C}_{6} \mathrm{H}_{2}\left(\mathrm{NO}_{2}\right)_{2}\right]_{2}\right\}_{(\mathrm{org})} \\
& 2(\mathrm{TTC})^{+}{ }_{(\mathrm{aq})}+\left\{\mathrm{MoO}_{2}\left[\mathrm{O}_{2} \mathrm{C}_{6} \mathrm{H}_{2}\left(\mathrm{NO}_{2}\right)_{2}\right]_{2}\right\}^{2-}{ }_{(\mathrm{aq})}
\end{aligned}
$$

Therefore, the ion-associated chelate of $\mathrm{Mo}(\mathrm{VI})-3,5-$ DNC with the cation of the monotetrazolium salt 2,3,5-triphenyl-2H-tetrazolium chloride (TTC) can be represented by the general formula (TTC) $)_{2}\left\{\mathrm{MoO}_{2}\left[\mathrm{O}_{2} \mathrm{C}_{6} \mathrm{H}_{2}\left(\mathrm{NO}_{2}\right)_{2}\right]_{2}\right\}$.

\section{6. Extraction Equilibria, True Molar Absorptivity, Recovery Factor and Structural Formula of the Ion-Associated Complex}

The association process in aqueous phase and the extraction equilibria were investigated and quantitatively characterized with respect to the following key constants: association constant $\beta$, distribution constant $K_{D}$, extraction constant $K_{e x}$ and recovery factor $R \%$. 
The association constant $\beta$ and the true molar absorptivity $\mathcal{E}$ were determined by the method of Komar-Tolmachev from equation (5): ${ }^{44}$

$$
\beta=(1 / \mathrm{n})^{\mathrm{n}} /\left[\varepsilon(\operatorname{tg} \alpha)^{\mathrm{n}+1}\right]
$$

where 1 is the cuvette thickness $(1=1 \mathrm{~cm}) ; \mathrm{n}$ - the molar ratio between the components independently determined (e.g. by the mobile equilibrium method, the straight-line method of Asmus or the method of continuous variations) $(\mathrm{n}=2), \varepsilon$ - the true molar absorptivity.

The true molar absorptivity $\varepsilon$ was determined by the method of Komar-Tolmachev (Figure 7) from the equation of a straight line $\mathrm{Y}=1.6762 \mathrm{X}+4.9692((\varepsilon=1 /(4.9692$ $\left.\left.\times 10^{-5}, \mathrm{~L} \mathrm{~mol}^{-1} \mathrm{~cm}^{-1}\right)\right)$ and its value is given in Table 1 , column 2 .

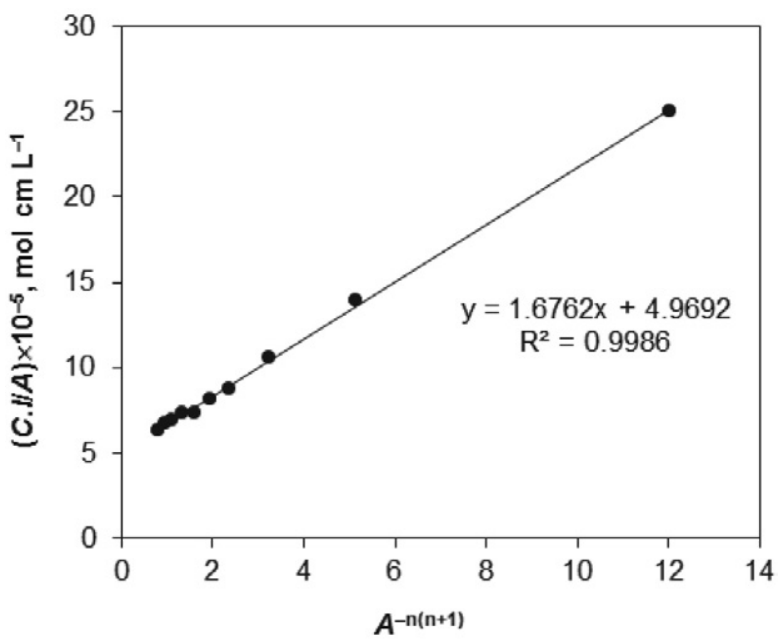

Figure 7. Dependency of $(C . l / A)$ on $A^{-\mathrm{n} /(\mathrm{n}+1)}$ (method of KomarTolmachev) $C=C_{\mathrm{Mo}(\mathrm{VI})} \mathrm{mol} \mathrm{L}^{-1} ; C_{\mathrm{TTC}}=2 C_{\mathrm{Mo}(\mathrm{VI})} \mathrm{mol} \mathrm{L}^{-1} ; C_{3,5-\mathrm{DNC}}=$ $1.2 \times 10^{-3} \mathrm{~mol} \mathrm{~L}^{-1} ; A$ - absorbance; $l$ - cell thickness, $l=1 \mathrm{~cm} ; \mathrm{n}=2$

The distribution constant $\left(K_{D}\right)$ was determined by the equation (6), where $A_{1}$ and $A_{3}$ are the absorbance (measured against blanks) obtained after a single and triple extraction, respectively.

$$
\begin{aligned}
& K_{D}=\left\{(\mathrm{TTC})_{2}\left\{\mathrm{MoO}_{2}\left[\mathrm{O}_{2} \mathrm{C}_{6} \mathrm{H}_{2}\left(\mathrm{NO}_{2}\right)_{2}\right]_{2}\right\}\right\}_{(\mathrm{org})} / \\
& \left\{(\mathrm{TTC})_{2}\left\{\mathrm{MoO}_{2}\left[\mathrm{O}_{2} \mathrm{C}_{6} \mathrm{H}_{2}\left(\mathrm{NO}_{2}\right)_{2}\right]_{2}\right\}\right\}_{(\mathrm{aq})}= \\
& A_{1} /\left(A_{3}-A_{1}\right)
\end{aligned}
$$
tion (7):

The recovery factor was determined from the equa-

$$
R \%=100 K_{D} /\left(K_{D}+1\right)
$$

The extraction constant $K_{e x}$ was calculated by two independent methods:

$$
\text { (i) } \log K_{e x}=\log K_{D}+\log \beta
$$

where $\beta$ was determined by the method of Komar-Tolmachev.

(ii) the method of Likussar-Boltz: ${ }^{45}$

The method uses the data from the method of continuous variations (Figure 6). The extraction constant $K_{e x}$ was calculated by the equation of Likussar-Boltz for molar ratio 1:2 (equation 9):

$$
\begin{aligned}
& \log K_{e x}=0.3522-2 \log K+\log \mathrm{Y}_{\max }- \\
& 3 \log \left(1-\mathrm{Y}_{\max }\right)
\end{aligned}
$$

where $K$ is the total concentration of reagents $-\left(K=C_{\mathrm{Mo}(\mathrm{VI})}\right.$ $\left.+C_{\mathrm{TTC}}=8.0 \times 10^{-5} \mathrm{~mol} \mathrm{~L}^{-1}\right) ; \mathrm{Y}_{\max }$ and $\left(1-\mathrm{Y}_{\max }\right)$ are determined by additionally plotted normalized absorption curve $\left(\mathrm{Y}_{\max }=0.689 ;\left(1-\mathrm{Y}_{\max }\right)=0.311\right)$ (Figure 6).

The values of the equilibrium constants and the recovery factor, describing quantitatively the equilibrium in the aqueous phase and the extraction of the ion-associated complex in the organic phase are presented in Table 3.

The results obtained by independent methods are statistically similar and confirm the proposed scheme of

\begin{tabular}{|c|c|}
\hline Equilibrium constant and recovery factor & Value \\
\hline 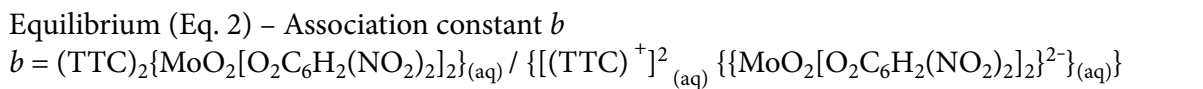 & $\log b=(9.42 \pm 1.08)^{\mathrm{a}}$ \\
\hline $\begin{array}{l}\text { Equilibrium (Eq. 3) - Distribution constant } K_{D} \\
K_{D}=\left\{(\mathrm{TTC})_{2}\left\{\mathrm{MoO}_{2}\left[\mathrm{O}_{2} \mathrm{C}_{6} \mathrm{H}_{2}\left(\mathrm{NO}_{2}\right)_{2}\right]_{2}\right\}\right\}_{(\text {org })} /\left\{(\mathrm{TTC})_{2}\left\{\mathrm{MoO}_{2}\left[\mathrm{O}_{2} \mathrm{C}_{6} \mathrm{H}_{2}\left(\mathrm{NO}_{2}\right)_{2}\right]_{2}\right\}\right\}_{(\mathrm{aq})}\end{array}$ & $\log K_{D}=(1.15 \pm 0.01)^{\mathrm{b}}$ \\
\hline $\begin{array}{l}\text { Equilibrium (Eq. 4) - Extraction constant } K_{e x} \\
K_{e x}=\left\{(\mathrm{TTC})_{2}\left\{\mathrm{MoO}_{2}\left[\mathrm{O}_{2} \mathrm{C}_{6} \mathrm{H}_{2}\left(\mathrm{NO}_{2}\right)_{2}\right]_{2}\right\}\right\}_{(\mathrm{org})} /\left\{\left\{[\mathrm{TTC}]^{+}\right\}_{(\mathrm{aq})}^{2}{ }^{\prime}{ }^{\prime} K_{e x}=(9.86 \pm 0.06)^{\mathrm{d}}\right.\end{array}$ & $\log K_{e x}=(10.57 \pm 1.09)^{c}$ \\
\hline Recovery factor $R \%$ & $R=(93.39 \pm 0.05) \% \mathrm{e}^{\mathrm{e}}$ \\
\hline
\end{tabular}
the process of complex formation of the ion-associated complex in the aqueous phase, its distribution between the aqueous and the organic phases and its extraction in chloroform. Based on this, the proposed structural formula of the ion-associated complex is represented in Figure 8 .

Table 3. Values of the equilibrium constants and the recovery factor

${ }^{a}$ Calculated by Komar-Tolmachev method (equation 5); ${ }^{\mathrm{b}}$ Calculated by equation (6); ${ }^{\mathrm{c}}$ Calculated by equation (8), where $\beta$ is determined by the Komar-Tolmachev method; ${ }^{\mathrm{d}}$ Calculated by Likussar-Boltz method (equation (9)); ${ }^{\mathrm{e}}$ Calculated by equation (7). 


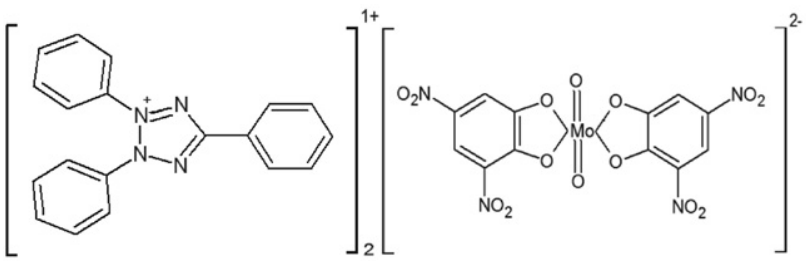

Figure 8. Structural formula of the ion-associated complex Mo(VI)-3,5-DNC-TTC

\section{Conclusion}

The equilibria of the complex formation of the anionic chelate of molybdenum(VI) with the bidentate ligand of 3,5-dinitrocatechol (3,5-DNC) and its extraction with the cation of 2,3,5-triphenyl-2H-tetrazolium chloride (TTC) in the form of an ion-associated complex in the liquid-liquid extraction system $\mathrm{Mo}(\mathrm{VI})-3,5$-DNC-TTC$\mathrm{H}_{2} \mathrm{O}-\mathrm{CHCl}_{3}$ was studied by spectrophotometry. In the presence of the monotetrazolium cation, the yellow-colored anionic chelate of $\mathrm{Mo}(\mathrm{VI})-3,5$-DNC forms an ion-associated complex well soluble in chloroform. The bulky organic molecule of the tetrazolium salt determined the extractability of the ion-associate in the organic phase. The optimum conditions for the association in aqueous phase and for extraction of the ion-associated complex $\mathrm{Mo}(\mathrm{VI})-3,5-\mathrm{DNC}-\mathrm{TTC}$ into chloroform were established. The effect of co-existing ions and reagents on the process of chelate formation and ion-association was studied. The validity of Beer's law was checked and the following analytical characteristics were calculated: the apparent molar absorptivity $\left(\varepsilon^{\prime}\right)$, the true molar absorptivity $(\varepsilon)$, the limit of detection $(L O D)$, the limit of quantification $(L O Q)$ and the Sandell's sensitivity (SS). From the analytical characteristics of the extraction system $\mathrm{Mo}(\mathrm{VI})-3,5-\mathrm{DNC}-\mathrm{TTC}-$ $\mathrm{H}_{2} \mathrm{O}-\mathrm{CHCl}_{3}$, it can be concluded that the ion-associate formed between the anionic chelate of $\mathrm{Mo}(\mathrm{VI})-3,5-\mathrm{DNC}$ and the monotetrazolium cation allows determinations of $\mathrm{Mo}(\mathrm{VI})$ with a high sensitivity. The equilibrium constants needed for the quantitative assessment of the extraction equilibrium were also calculated, i.e. the association constant $(\beta)$, the distribution constant $\left(K_{D}\right)$, the extraction constant $\left(K_{e x}\right)$ and the recovery factor $(R \%)$. The molar ratio of the components, determined by independent methods, shows that the ion-associated complex could be represented with the general formula (TTC) ${ }_{2}\left\{\mathrm{MoO}_{2}\left[\mathrm{O}_{2} \mathrm{C}_{6} \mathrm{H}_{2}\right.\right.$ $\left.\left.\left(\mathrm{NO}_{2}\right)_{2}\right]_{2}\right\}$. A corresponding reaction scheme and a structural formula of the ion-associated complex were also suggested.

\section{Acknowledgements}

The authors would like to thank the Research Fund of the University of Plovdiv for the financial support of the current research.

\section{References}

1. Y. D. Tretyakov, L. I. Martinenko, A. N. Grigorev: Inorganic Chemistry, Moscow University, Moscow, Russia, 2007, pp. 309-369

2. F. A. Cotton, G. Wilkinson, C. A. Murillo, M. Bochmann: Advanced Inorganic Chemistry, sixth ed., Wiley Publishers, New Jersey, 1999, pp. 844-883.

3. V. V. Skopenko, A. Y. Tsivadze, L. I. Sabranskiy, A. D. Garnovskiy: Coordination Chemistry, Akademkniga, Moscow, Russia, 2007, pp. 76-81.

4. A. P. Vinogradov: Analytical Chemistry of Elements - Molybdenum, Nauka, Moscow, Russia, 1962, pp. 25-97.

5. V. M. Ivanov, G. A. Kochelaeva, J. Anal. Chem. 2003, 58, 31-37. DOI:10.1023/A:1021830013973

6. M. L. Harikumaran Nair, Anju. S. Appukuttan, J. Korean Chem. Soc. 2012, 56, 217-227. DOI:10.5012/jkcs.2012.56.2.217

7. T. Nakamura, S. Nishihama, K. Yoshizuka, Solvent Extr. Res. Dev. 2009, 16, 47-56.

8. L. Xue, D. Deng, Y. Xu, Q. Wang, Russ. J. Coord. Chem. 2016, 42, 137-142. DOI:10.1134/S1070328416020093

9. V. M. Ivanov, G. A. Kochelaeva, G. V. Prokhorova, J. Anal. Chem. 2002, 57, 758-772. DOI:10.1023/A:1020015521584

10. P. A. Petrov, M. Y. Afonin, D. Y. Naumov, S. N. Konchenko, A. V. Piskunov, Russ. J. Coord. Chem. 2015, 41, 31-36. DOI:10.1134/S1070328415010078

11. W. X. Xu, W. H. Li, Russ. J. Coord. Chem. 2012, 38, 92-98. DOI:10.1134/S107032841202011X

12. F. L. Fan, F. A. Lei, L. N. Zhang, J. Bai, M. S. Lin, H. J. Ding, X. L. Wu, D. Nayak, Z. Qin, Solvent Extr. Ion Exch. 2009, 27, 395-407. DOI:10.1080/07366290902821305

13. S. Tascioglu, E. Kaki, S. Tascioglu, J. Appl. Spectrosc. 2012, 79, 540-546. DOI:10.1007/s10812-012-9637-8

14. S. J. Kokake, A. A. Gavande, V. K. Vikhe, H. R. Aher, S.R. Kuchekar, Indian J. Chem. Techn. 2010, 17, 154-157.

15. J. Y. Lee, J. R.Kumar, H. S. Jeon, J. S. Kim, Chem. Eng. 2010, 54, 27-31. DOI:10.3311/pp.ch.2010-1.04

16. P. K. Parhi, Kyung-Ho Park, H. Kim, J. Park, Hydrometallurgy 2011, 105, 195-200. DOI:10.1016/j.hydromet.2010.09.004

17. J. Kim, S. Park, S. Kim, Fluid Phase Equilib. 2010, 295, 172-176. DOI:10.1016/j.fluid.2010.04.016

18. R. Colopado-Peralta, M. Sanches-Vazquez, I. F. Hernandes-Ahuactzi, S. A., Sanchez-Ruiz, R. Contreras, A. Flores-Parra, S. E. Castillo-Blum, Polyhedron 2012, 48, 72-79. DOI:10.1016/j.poly.2012.09.013

19. A. T. Pilipenko, M. M. Tananayko: Mixed Ligands and Mixed Metal Complexes and their Application in Analytical Chemistry, Khimiya, Moscow, Russia, 1983, pp. 101-125.

20. J. L. Martinez-Vidal, A. R. Fernandez-Alba, F. Salinas, Analyst 1990, 3, 329-331. DOI:10.1039/an9901500329

21. M. L. C. Passos, M. Lucia M. F. S. Saraiva, J. F. C. Lima, Anal. Sci. 2005, 12, 1509-1515. DOI:10.2116/analsci.21.1509

22. K. Gavazov, A. Dimitrov, V. Lekova, Russ. Chem. Rev. 2007, 76, 169-179. DOI:10.1070/RC2007v076n02ABEH003655

23. K. B. Gavazov, V. D. Lekova, G. I. Patrovov, Acta Chim. Slov. 2006, 53, 506-511.

24. V. Divarova, V. Lekova, P. Racheva, K. Stojnova, A. Dimitrov, 
Acta Chim. Slov. 2014, 61, 813-818.

25. V. V. Divarova, K. T. Stojnova P. V. Racheva, V. D. Lekova, J. Appl. Spectrosc. 2017, 84, 231-236.

DOI:10.1007/s10812-017-0456-9

26. V. Divarova, K. Stojnova, P. Racheva, V. Lekova, Acta Chim. Slov. 2016, 63, 97-103. DOI:10.17344/acsi.2015.1987

27. P. Racheva, K. Stojnova, V. Divarova, V. Lekova, Acta Chim. Slov. 2017, 64, 365-372. DOI:10.17344/acsi.2017.3214

28. K. Stojnova, P. Racheva, V. Divarova, K. Bozhinova, V. Lekova, Russ. J. Inorg. Chem. 2017, 62, 249-256.

DOI: $10.1134 /$ S0036023617020188

29. K. Stojnova, V. Divarova, P. Racheva, K. Bozhinova, V. Lekova, Acta Chim. Slov. 2018, 65, 213-220.

DOI:10.17344/acsi.2017.3860

30. K. Stojnova, V. Lekova, Acta Chim. Slov. 2019, 66, 360-366. DOI:10.17344/acsi.2018.4862

31. K. T. Stojnova, V. D. Lekova, Russ. J. Inorg. Chem. 2019, 64, 1235-1241. DOI:10.1134/S0036023619100152

32. A. W. Nineham, Chem. Rev. 1955, 55, 355-483.

DOI:10.1021/cr50002a004

33. H. Şenöz, Hacettepe J. Biol. \& Chem. 2012, 40, 293-301.

34. A. K. Babko, A. T. Pilipenko: Photometric Analysis, Khimiya, Moscow, Russia, 1968, pp. 159-164.

35. J. Inczédy: Analytical Applications of Complex Equilibria, Mir, Moscow, Russia, 1979, pp. 225-242.
36. T. P. Rao, M. L. P. Reddy, A. R. Pillai, Talanta 1998, 46, 765-813. DOI:10.1016/S0039-9140(97)00262-2

37. A. N. Turanov, V. K. Karandashev, V. E. Baulin, E. V. Kirillov, S. V. Kirillov, V. N. Rychkov, A. Yu. Tsivadze, Russ. J. Inorg. Chem. 2016, 61, 1335-1338. DOI:10.1134/S0036023616100211

38. A. N. Turanov, V. K. Karandashev, O. I. Artyushin, E. V. Sharova, Solvent Extr. Ion Exch. 2015, 33, 540-553. DOI:10.1080/07366299.2015.1067052

39. V. A. Mikhaylov: Extraction Chemistry, Nauka, Novosibirsk, Russia, 1984, pp. 194-249.

40. G. Kristian: Analytical Chemistry, BINOM, Moscow, Russia, 2009, pp. 414-426.

41. K. Stojnova, V. Divarova, P. Racheva, K. Bozhinova, V. Lekova, Acta Chim. Slov. 2016, 63, 654-660.

DOI:10.17344/acsi.2016.2513

42. Z. Marczenko, M. Baltcerzak: UV-Vis Spectrophotometric Methods Applied to the Inorganic Analysis, BINOM, Moscow, Russia, 2009, pp. 169-174.

43. B. F. Quin, R. R. Brooks, Anal. Chim. Acta 1975, 74, 75-84. DOI:10.1016/S0003-2670(01)82781-1

44. M. I. Bulatov, I. P. Kalinkin: Practical Handbook on Photometric Methods of Analysis, Khimiya, Leningrad, Russia, 1986, pp. 174-264.

45. W. Likussar, D. F. Boltz, Anal. Chem. 1971, 43, 1265-1272. DOI:10.1021/ac60304a006

\section{Povzetek}

$\mathrm{S}$ spektrofotometričnimi metodami smo raziskali tvorbo kompleksa med anionskim kelatom molibdena(VI) z dvoveznim ligandom 3,5-dinitrokateholom (3,5-DNC) in ionski asociat s kationom 2,3,5-trifenil-2H-tetrazolijevim kloridom (TTC) v tekoče-tekoče ekstrakcijskem sistemu $\mathrm{Mo}(\mathrm{VI})-3,5-\mathrm{DNC}-\mathrm{TTC}-\mathrm{H}_{2} \mathrm{O}-\mathrm{CHCl}_{3}$. Preverili smo veljavnost Beerovega zakona ter izračunali nekatere analizne karakteristike pri optimalnih pogojih za tvorbo kelata in ekstrakcijo. Raziskali smo vpliv različnih prisotnih ionov in reagentov na proces tvorbe kelata in ionskega asociata. Molsko razmerje komponent v ionsko asociiranem kompleksu Mo(VI)-3,5-DNC-TTC smo določili na podlagi neodvisnih metod. Asociacijski proces v vodni fazi in ekstrakcijsko ravnotežje smo proučili ter kvantitativno karakterizirali sledeče ključne konstante: konstanto asociacije, porazdelitveno in ekstrakcijsko konstanto ter izkoristek ekstrakcije. Na podlagi dobljenih podatkov je predlagana reakcijska shema, splošna formula in struktura kompleksa.

Except when otherwise noted, articles in this journal are published under the terms and conditions of the Creative Commons Attribution 4.0 International License 